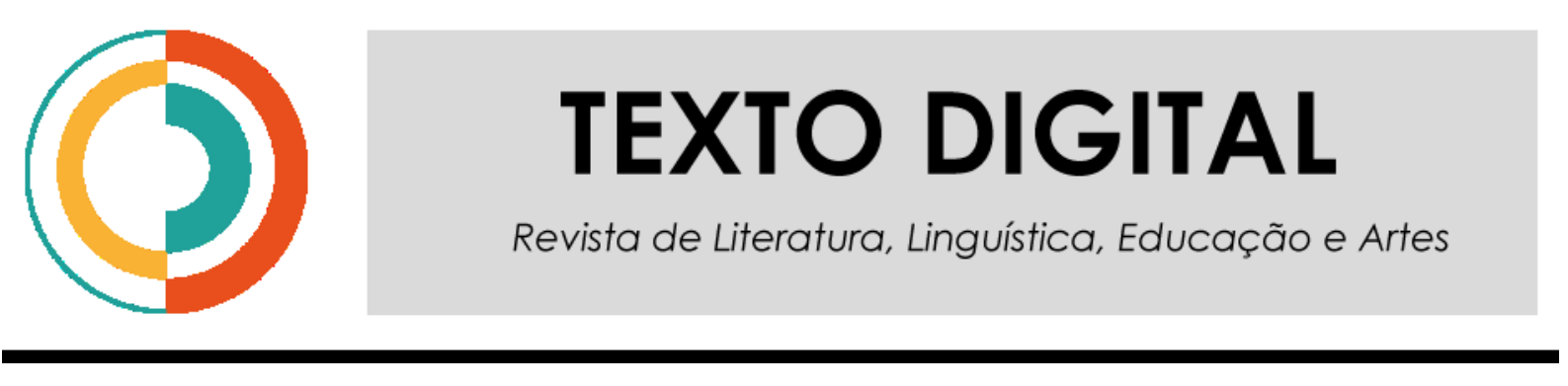

\title{
Migrações e regressos
}

\section{Migrations and returns}

\section{Lourdes Malerba Gabrielli ${ }^{a}$}

a Pontifícia Universidade Católica de São Paulo, São Paulo, Brasil - lourdes.gabrielli@gmail.com

Palavras-chave: Intertextualidade. Processo. Verbi-vocovisual. Barroco. Tradução.

\section{Keywords:}

Intertextuality. Process. Verbi-voco-visual. Baroque. Translation.
Resumo: O presente artigo tem por objetivo analisar teórica e artisticamente os diferentes momentos da produção artística de Wilton Azevedo. Desde os primeiros anos de carreira, com sua produção visual, passando por experimentações sonoras, como a realizada a partir da obra Catatau de Paulo Leminsky e as performances do Duo Pantharei. Para tal serão utilizadas as ideias de tradução e do barroco, com teóricos como SARDUY e LOTMAN. O artigo mostra a continuidade da obra do artista em seu objetivo, sempre presente, de trabalhar a intertextualidade.

Abstract: The present article aims to analyse theoretical and artistic procedures in different moments of the artistic production of Wilton Azevedo. From the earliest years of his career, with his visual production, through sound experiments, such as the one realized with Catatau by Paulo Leminsky and the performances of Duo Pantharei. For this will be adopted the ideas of translation and baroque, with theorists as SARDUY and LOTMAN. The article shows the continuity of the artist's work in his ever present objective of working on intertextuality. 
Aqui tem todas as cores do mundo. Escolha seu mundo conforme suas cores. Wilton Azevedo em sua primeira caixa de tintas

\section{INTRODUÇÃO}

As ideias de transdisciplinaridade ou imbricações são fortemente presentes na experiência contemporânea do viver, para não dizer definidoras. $O$ dia a dia faz perceber que os fenômenos estão sempre em processo, aos quais são acrescidos - ou subtraídos elementos/acontecimentos. E para explicar os fenômenos da comunicação que vivemos, com sua característica movente, também se pode falar em polifonia, fronteiras, substituição, traduções, migrações, regressos etc. A vida tem se mostrado polifônica, e nos adaptamos a esta dinâmica.

Ao inserir a arte na vida, o artista vive ainda mais intensamente os fenômenos cujos nomes trazem os prefixos inter ou multi. Wilton Azevedo viveu a arte e desde muito jovem reconheceu que estava num terreno modeviço entre os códigos. Fazia as experiências com os recursos de que dispunha e tirava dos suportes sempre o melhor na hora de comunicar algo. Ai estava seu grande potencial de criador de linguagem.

Parte da produção do seu período inicial como artista visual (nos anos 70 e 80) foi exposta e muitos trabalhos distribuídos entre amigos, e de algumas dessas séries, poucos registros existem. AZEVEDO sempre foi um exímio desenhista. Fazia quadrinhos, criava personagens, tiras e participou algumas vezes do Salão Internacional de Humor de Piracicaba. Trabalhava em papel ou tela, com aquarela, lápis ou acrílico, mas para além dos materiais comuns, fabricava giz de cera e tintas artesanalmente, utilizava solventes diversos, desde cera de abelha até resina de árvores e a velha clara de ovo. Tinha em seu ateliê vários frascos de pigmentos com cores diferentes de terra e vegetais, que apanhava por onde passava. Experimentava também com papéis artesanais, em formatos inusitados, que secavam no quintal do ateliê da Mooca.

Dessa parte de sua história já é possível vislumbrar o artista multidisciplinar e multilinguagens. Uma dessas séries era feita com papel Paraná esculpido, de cujas fendas, que criava com buril, AZEVEDO fazia surgirem cores esfumaçadas que contrastavam com a cor parda do papel. Uma outra ainda, essa já mostrando sua preocupação com a interação entre o verbal e o visual, foi construída em papel canson e pastel seco. Nestas obras apareciam 
desenhos orgânicos, corpos esvoaçantes nos quais pediu que eu inserisse poemas. Sugeri então termos em grego, definidores dos movimentos que os desenhos traziam, que foram inseridos em preto nos locais onde ele determinava.

Depois dessa vieram muitas experiências verbo-visuais, que ele próprio relata na introdução de seu trabalho de pós doutoramento, encorpadas pelo contato com Décio Pignatari e Philadelpho Menezes ${ }^{1}$. Mas Wilton Azevedo não parou no verbo-visual. No final dos anos 80 realizamos, em conjunto, um trabalho de leitura de uma página selecionada do Catatau de Paulo Leminski (1975). Eram os tempos produtivos e de novos amigos do mestrado em Comunicação e Semiótica na PUC-SP. Selecionamos a página 203, a partir das sonoridades possíveis que seriam geradas em leituras sobrepostas. Gravei o texto várias vezes, reinterpretando partes, e Wilton mixou. A oralidade já o encantava.

A partir dessas experiências é possível entender porque sua obra enveredou para o ambiente digital. Lá estava o suporte - e também a linguagem - que permitia todas as experiências que o papel e uma mesa de gravação de quatro canais não comportavam mais. Ao migrar para a performance, permaneceram presentes o texto, a imagem, o elemento sonoro e a espacialização.

Wilton Azevedo construiu uma vida e uma obra polifônicas. E essa sua característica, que esbanjou produção e inovação nos meio digitais, estava presente desde sua primeira caixa de tintas. Foi um artista sem fronteiras entre vida e arte e construiu uma obra em rica tradução inter e intracódigos.

\section{A TRADUÇÃO NAS PERFORMANCES DO DUO PANTHAREI}

As performances do Duo Pantharei, das quais participam Wilton Azevedo e Sergio Basbaum, disponíveis no youtube (https://www.youtube.com/watch?v=g4WcKwWKSRM) mostram elementos dos códigos verbal, visual e sonoro espacializados, interseccionados em vários níveis. Estas imbricações, em diferentes temperaturas, se dão a partir de elementos de linguagem que migram, num processo de transposição de fronteiras semióticas - a tradução.

${ }^{1}$ Décio Pignatari foi professor, teórico e poeta do movimento concreto brasileiro e Philadelpho Menezes, também poeta, organizou mostras de poesia visual. 
Um sistema semiótico, seja ele verbal, visual ou sonoro, traz para dentro da fronteira outro sistema, com o objetivo de criar diálogo entre eles e torná-lo legível dentro deste espaço cultural. A transposição da fronteira requer a tradução de um sistema semiótico para outro, considerando-se as linguagens que estiverem implicadas no processo.

Se os códigos constituintes mantêm seus elementos indiciadores, e é possível perceber suas potencialidades comunicativas individualmente, trata-se provavelmente de um nível menor de imbricação entre sintaxes. Da mesma forma, sem tornar homogêneos os elementos comunicacionais presentes, a inovação de linguagem se dá quando os códigos atuam comunicando de forma equivalente, quando a mensagem chega ao receptor sem que este se ocupe em elencar elementos presentes, mas apenas navegue pelo novo código, um terceiro, resultante da presença de dois iniciais. ${ }^{2}$

Assim, elementos verbais migram para a visualidade e são decodificados como letras, conservando, entretanto, interpretantes visuais. Em alguns casos, os elementos verbais mantêm veiculados seus conteúdos, mas acrescentam a eles significações advindas da visualidade. Transitar para a visualidade neste contexto quer dizer que a informação verbal ganha o suporte visual, seja a tela, a escultura, o desenho, a instalação ou outro.

Em outros casos, a informação verbal se dissipa completamente, quando os elementos visuais passam a ser portadores de significado, para além da letra/palavra/frase. A espacialização, a escolha tipográfica, contraste, entreletras, entrelinhas, entre outros, passam a ser os signos que comunicam.

Elementos verbais migram para o suporte visual, sucumbem ao ambiente e são decodificados predominantemente como imagem. É possível identificar significações verbais, mas algumas vezes trata-se de reminiscências, pois os recursos da verbalidade foram incorporados pela visualidade.

Em algumas representações parecem letras, mas são desenhos, em outras, são letras, mas a força da informação se concentra no que nelas é imagem. O elemento visual se infiltra na informação verbal. Da mesma forma, o elemento sonoro funde-se à visualidade e aos signos verbais em diferentes níveis, e essas migrações são fator de inovação na construção da obra.

\footnotetext{
${ }^{2}$ Estas ideias estão presentes em LOTMAN (1996, p. 402) ao mencionar níveis de tradução nas diferentes
} semiosferas. 
Severo Sarduy (MORENO,1979, p. 161 -176), ao estudar o barroco, permite analisar os graus de interação através do conceito de paródia. Para o autor, a paródia se dá quando um texto possui outro, subjacente, um subtexto. Trata-se de uma rede de conexões, intertextual, que se subdivide em citação e incorporação.

Citação é um processo de superposição, equivalente visual da colagem, de forma que os elementos não se modificam, como constituintes que são de um diálogo. Já a incorporação apresenta um tipo de diálogo em que os textos se fundem, sem deixar marcas de sua individualidade. Segundo SARDUY, "tingindo suas redes, modificando com suas texturas sua geologia: a reminiscência”.

Nas performances do Duo Pantharei, informação sonora, textual e visual se fundem, tornando-se possível observar a informação verbal na visualidade da palavra, ou o signo visual contido na espacialização do texto, bem como as sonoridades que fazem incorporar os outros elementos presentes na cena.

Os artistas provocam um processo de tradução, uma espécie de movimento latente, sempre presente, que tem como pano de fundo a permanente criação e inovação, em construção constante.

\section{OS PROCEDIMENTOS BARROCOS NA LEITURA DE CATATAU}

Ao ler e mixar as palavras/frases de Catatau, AZEVEDO operava como um bricoleur, trabalhando artesanalmente, atento ao processo de construção do poeta Paulo Leminski. Catatau propõe uma narrativa por bricolagem que aponta para o olhar individual, para a ideia de esculpir palavras.

O livro transborda e ultrapassa os limites do registro de escrita fixa e opera baseado no conceito de intertextualidade, de ultrapassar fronteiras tornando-as tênues e não-definidas, valendo-se do elemento cultural para sua melhor definição. Limite e excesso são ações culturais: ao forçar o limite de um sistema fechado, sobrevem as situaçoes de tensão, e a ultrapassagem é a saída do contorno, o excesso ${ }^{3}$. Ao gravar e sobrepor as vozes, AZEVEDO

\footnotetext{
${ }^{3}$ Estas ideias encontram-se exploradas tanto em MORIN (2001, p. 28-53) quanto em BAKHTIN (2000, p. 404)
} 
trabalha com a ideia de limites e sua ultrapassagem na compreensão da ponte que se estabelece entre a escrita fixa e a escritura movente da oralidade.

A ideia de bricolagem, por sua vez, aponta para conceitos do barroco. Segundo SARDUY (MORENO,1979, p. 161 -176), no procedimento barroco de artificialização, um conceito é acrescido de elementos e torna-se "ironicamente" artificial. Isso pode se dar de três maneiras. A primeira é a substituição, quando o significante é substituído por outro, afastado dele. $\mathrm{Na}$ proliferação, a segunda, o significante é substituído por uma cadeia de significantes; e na condensação, a terceira, se dá uma fusão ou intercâmbio de elementos, com perda de autonomia das partes.

Considerando a ideia de substituição por uma cadeia de significantes, na proliferação, encontra-se uma das principais características da bricolagem, onde há uma "enumeração disparatada de elementos", uma acumulação de nódulos de significação. São unidades heterogêneas pois mantêm sua autonomia, e formam um discurso polifônico, uma "alegria periférica", ainda segundo SARDUY.

A polifonia em Catatau é ausência de linearidade, e tem este caráter pois não tem centro possível. É a exuberancia barroca, que se dá por incrustrações e imbricações de elementos que trazem a noção de descontinuidade, inacabamento e não-ortogonalidade.

É possivel encontrar esta mesma polifonia na escritura expandida, termo que AZEVEDO utilizou ao falar de sua produção no ambiente digital, e que definia como "uma produção que não necessita de códigos matriciais isolados". O artista aponta para estas questões em artigo da revista Abralic (2012):

\footnotetext{
"A não existência de significados prontos quando se trata do exercício de linguagem, sobretudo a poética. Leitura feita por varredura, como um scanner digital. Além das reconfigurações que exigem o tempo todo a participação ativa tanto do emissor quanto do receptor, especialmente dos meios digitais.

Sociedades moventes sempre viveram, de fato, o que é movente, não é apenas a voz, nem os códigos, nem tampouco o papel de emissor e receptor, mas a vida, o ambiente (que virou ambiência) e nós mesmos.

O tempo todo estudamos e vivemos interfaces, mobilidade, intertextualidade, intersemioses, experimentação, polifonia. É impressionante como lidamos com o não-ser em nosso dia a dia. E ainda conseguimos ser".
} 
Em entrevista publicada na revista TXT (2007), AZEVEDO fala de três períodos da escritura. O primeiro é o período das escrituras matriciais. Depois a fase das escrituras intermediarias, quando as intersecções não permitem que as matrizes se percam. E por fim a escritura expandida, contemporânea, "em que há o rompimento das matrizes e a perda dos sistemas matriciais. A Poesia Sonora hoje está fundida a outros códigos que geram signos em expansão".

O conceito de escritura expandida que o artista utiliza para definir seu trabalho na poesia digital define também o início de sua produção artística, se não considerarmos, obviamente, os suportes então utilizados para divulgar essa produção.

\section{IDEIAS EXPANDIDAS}

AZEVEDO utiliza, em sua obra das duas últimas décadas, conceitos que já empregava em sua produção das primeiras experiências.

Em sua pesquisa de pós doutoramento (2009) fala em "miscigenação de linguagens" (p. 15), "trânsito sígnico das mídias digitais" (p. 171), “intermediaridade” (p. 113), “imprevisibilidade" (p. 117), e estudar sua obra inicial, demanda os mesmos conceitos.

Em sua obra, fica claro que ele sabia o tempo todo onde queria chegar e construiu seu passo a passo artístico com o objetivo que ele, desde o começo, já conhecia. Seu pós-doutoramento traz muitas mostras da clareza de seu processo artístico e também como estudioso da comunicação e da arte (2009, p. 8):

\footnotetext{
"A poesia digital deixa, a cada etapa, mais evidente que a redundância de suas articulações sígnicas se faz presente como poética, mas não é a redundância promovida pela cultura POP, e sim a exaustão, o excesso, como processo de estranhamento que cria extensões de seus signos sem mais ter a necessidade de conter palavras."
}

Em sociedades moventes como as latinas, nas quais estão presentes as ideias de incompletude, de um projeto inconcluso de significação, vive-se de maneira processual. Esta ideia de processo presente na vida define a maneira de viver, não demandando esforço algum. 
Trabalhar para que estes conceitos migrem para a expressão artística e regressem para a vida é o que faz Wilton Azevedo transitar com tanta facilidade no universo da arte movente que praticou.

\section{REFERÊNCIAS}

AZEVEDO, W. Interpoesia. O início da Escritura Expandida. Université Paris 8 Laboratoire de Paragraphe. Pós-doutorado, sob a supervisão do Prof. Dr. Philippe Bootz. Paris, 2009. Disponível em: https://elmcip.net/critical-writing/interpoesia-o-inicio-daescritura-expandida. Acesso em: 07 jun. 2018.

AZEVEDO, W.; SALES, C. A Literatura Digital e sua Escritura Expandida. Revista Abralic, Revista Brasileira de Literatura Comparada, v. 14, n. 20, 2012. Disponível em: http://revista.abralic.org.br/index.php/revista/article/view/281. Acesso em: 5 jun. 2018.

BAKHTIN, M. Estética da Criação Verbal. São Paulo: Martins Fontes, 2000.

LEMINSKI. P. Catatau. Curitiba: Edição do Autor, 1975.

LOTMAN, I. La Semiosfera I. Madri: Cátedra, 1996.

MARQUES, B. Entrevista Wilton Azevedo. Revista Txt: Leituras Transdisciplinares de Telas e Textos. Belo Horizonte, v. 3, n. 6, p.78-81, 2007. Disponível em:

https://seer.ufmg.br/index.php/txt/article/view/9153. Acesso em: 05 jun. 2018.

MORENO, C. F. (Org.). América Latina em sua Literatura. São Paulo: Perspectiva, 1979.

MORIN, E. O Método 4. As idéias. Porto Alegre: Sulina, 2001.

SARDUY, S. Barroco. Lisboa: Veja, s/d. 